\title{
Long-term follow-up of a patient with Uhl anomaly after biologic and mechanical circulatory support
}

\author{
Evgenij V. Potapov, MD, PhD, ${ }^{\mathrm{a}}$ Tomohiro Saito, MD, ${ }^{\mathrm{a}}$ Alain Carpentier, MD, $\mathrm{PhD},{ }^{\mathrm{b}}$ \\ Roland Hetzer, $\mathrm{MD}, \mathrm{PhD},{ }^{\mathrm{a}}$ and Thomas Krabatsch, $\mathrm{MD}, \mathrm{PhD}^{\mathrm{a}}$
}

See related commentary on pages e116-7.

Uhl anomaly is exceedingly rare and is characterized by right ventricular cardiomyopathy with absence of the myocardial layer of the right ventricle (RV) parietal wall, resulting in parchment RV. ${ }^{1}$ Until now, successful surgical treatment options have been bidirectional Glenn anastomosis with the creation of an atrial septal defect and tricuspid valve (TV) closure, one-and-a-half ventricle repair with partial right ventriculectomy, and heart transplantation (HTx).,3

\section{CLINICAL SUMMARY}

In 1987 a 13-year-old boy experienced syncope and examination showed severe TV regurgitation. Uhl anomaly was diagnosed by one of the authors (AC) in Paris in 1988 and the patient underwent TV repair and cardiomyoplasty with the latissimus dorsi muscle in 1990 performed by the same physician. ${ }^{4}$ The histologic evaluation supported the diagnosis. During follow-up the wrapped latissimus dorsi muscle remained fully functional, the mitral valve (MV) and TV were competent, and the left ventricular ejection fraction was $>50 \%$. The patient's M. latissimus dorsi pacemaker was exchanged several times, most recently in 2011 with a special custom-made device.

During April 2014 the patient presented at an external hospital with dyspnea at rest. Echocardiography showed severe MV and trivial TV regurgitation with normal left ventricular ejection fraction and diameter. The RV and right atrium (RA) were dilated; catheterization showed normal RV end-diastolic and central venous pressures. Urgent

\footnotetext{
From the Department of Cardiothoracic and Vascular Surgery, ${ }^{\mathrm{a}}$ Deutsches Herzzentrum Berlin, Berlin, Germany; and the Department of Cardiovascular Surgery and Organ Transplantation, ${ }^{\mathrm{b}}$ Georges Pompidou European Hospital, Université Paris-Descartes, Paris, France.

EVP performed the second operation, provided case interpretation, and wrote the manuscript; TS assisted during surgery, conducted the literature search, prepared the figures, and wrote the manuscript; $\mathrm{AC}$ performed the first operation and edited the manuscript; RH provided advice and case interpretation; and TK performed the second operation and provided case interpretation.

Disclosures: Authors have nothing to disclose with regard to commercial support.

Received for publication Nov 22, 2014; revisions received Jan 16, 2015; accepted for publication Jan 29, 2015; available ahead of print March 24, 2015.

Address for reprints: Evgenij V. Potapov, MD, PhD, Department of Cardiothoracic and Vascular Surgery, Deutsches Herzzentrum Berlin, Augustenburger Platz 1, 13353 Berlin, Germany (E-mail: Potapov@dhzb.de).

J Thorac Cardiovasc Surg 2015;149:e115-6

$0022-5223 / \$ 36.00$

Copyright (c) 2015 by The American Association for Thoracic Surgery

http://dx.doi.org/10.1016/j.jtcvs.2015.02.037
}

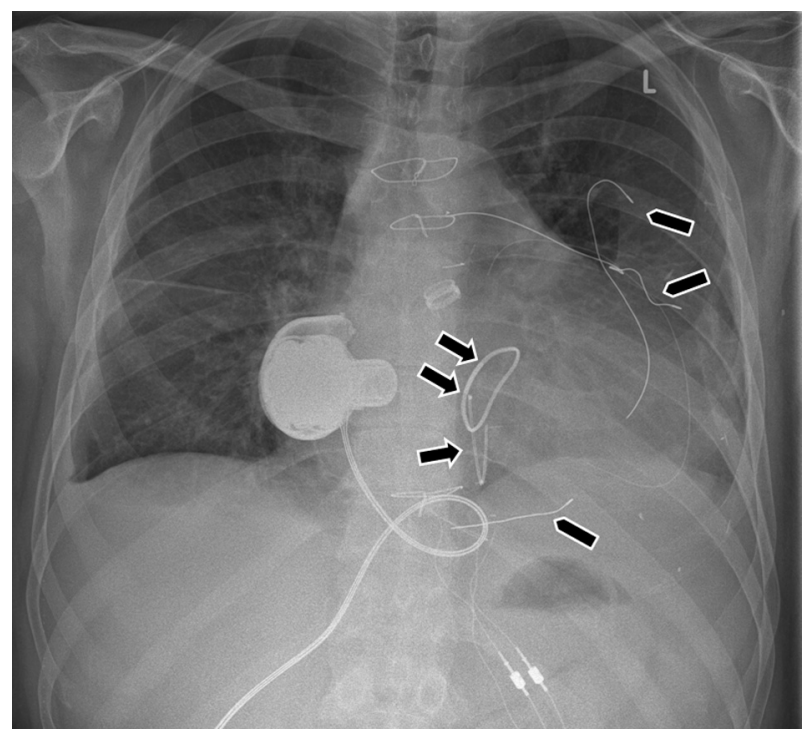

FIGURE 1. Posteroanterior chest radiograph view at discharge on postoperative day 14. The arrow indicates the tricuspid ring and the double arrows indicate the mitral ring. Arrowheads point to the remaining cables of the latissumus dorsi muscle pacemaker.

MV repair was performed 2 weeks later. After median sternotomy the latissimus dorsi muscle was divided to access the MV. Postoperatively the patient experienced RV failure requiring support with a right ventricular assist device (RVAD) (CentriMag; Thoratec, Pleasanton, Calif), which was implanted via the RA and the pulmonary artery (PA).

Because severe hemodynamic instability developed 10 days later, the patient was transferred to our institution and immediately taken to the operating room, where cardiac tamponade was resolved; the RVAD flow consequently improved to up to $8 \mathrm{~L} / \mathrm{min}$. After 1 month on the RVAD the patient's renal and liver function recovered and he was fully mobilized. Weaning from the RVAD failed because the huge RV was not contractile and the RA had become dilated.

In July 2014 the temporary RVAD was exchanged for a HeartWare HVAD (HeartWare, Framingham, Mass) offpump, as described by our group. ${ }^{5}$ The inflow cannula was implanted into the RA and the outflow graft into the PA (Figures 1 and 2). Intraoperatively measured mean PA pressure was 10 to $15 \mathrm{~mm} \mathrm{Hg}$. The postoperative course was uneventful and the patient was discharged home, with RVAD flow of 5 to $6 \mathrm{~L} / \mathrm{min}$. Histologic evaluation of the RA showed absence of the myocardial layer with the atrial wall consisting of fibrotic tissue-findings similar to those described for the RV in Uhl anomaly. ${ }^{1}$ 


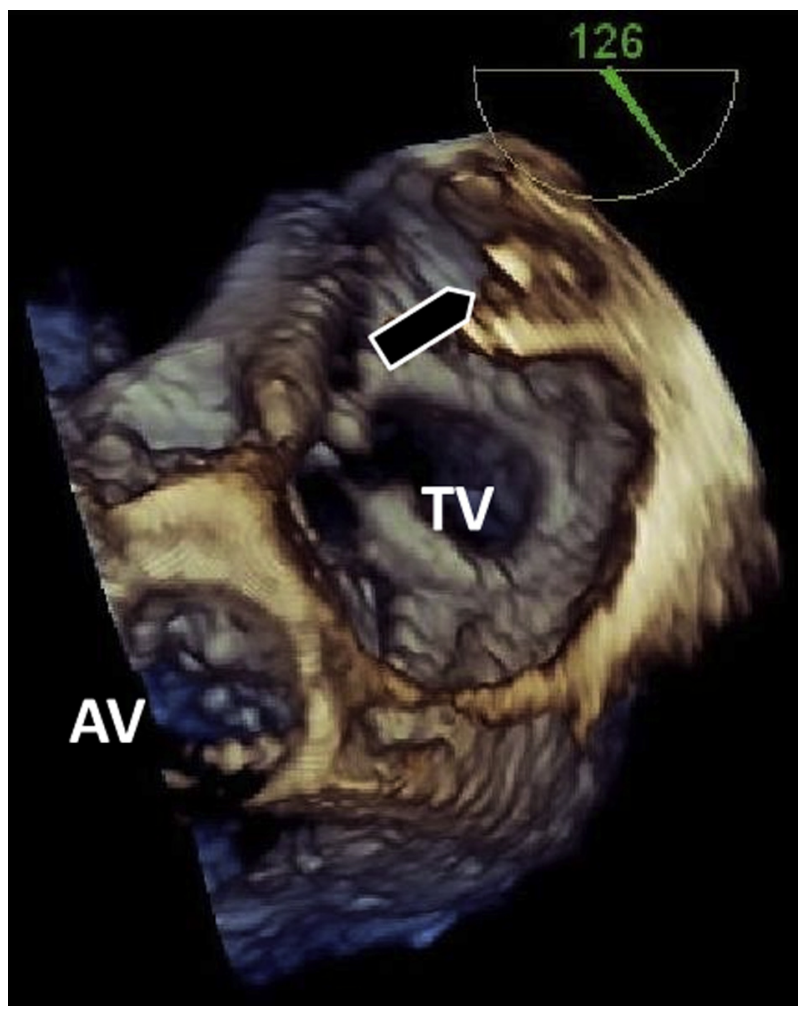

FIGURE 2. Intraoperative real-time 3-dimensional transesophageal echocardiogram showing the HeartWare HVAD inflow cannula (arrowhead) to be placed in a suitable position toward the atrial septum. $A V$, Aortic valve; $T V$, tricuspid valve.

\section{DISCUSSION}

This longest reported follow-up of a patient with Uhl anomaly shows the success of combined biologic and mechanical support of a RV over almost 25 years. Clearly, the extremely low incidence of the disease does not justify reestablishing the forgotten cardiomyoplasty using the latissimus dorsi muscle, but the second step-mechanical circulatory support—offers in this situation a reliable tool as a bridge to HTx. Our patient is currently listed for HTx and again biologic circulatory support will be the next long-term solution.

In this particular case the severely regurgitant MV might have been better approached by a minimally invasive right thoracotomy or even percutaneously by a Mitraclip device (Abbott Laboratories, North Chicago, Ill) to avoid damage to the latissimus dorsi.

We chose the RA as the site for the inflow cannula of the HeartWare HVAD for 2 reasons: the RA cavity was large and severe adhesions of the RV made it difficult to access the diaphragm wall. The free wall of the RV was accessible, but the distance to the sternum was too short and there would have been a risk of pump impression and obstruction of the inflow cannula. ${ }^{5}$

Besides Glenn anastomosis and HTx in Uhl anomaly patients, our case shows a new treatment option: RVAD as a bridge to HTx or for permanent support.

The authors thank Anne Gale for providing editorial assistance.

\section{References}

1. Uhl HS. A previously undescribed congenital malformation of the heart: almost total absence of the myocardium of the right ventricle. Bull Johns Hopkins Hosp. 1952;91:197-205.

2. Azhari N, Assaqqat M, Bulbul Z. Successful surgical repair of Uhl's anomaly Cardiol Young. 2002;12:192-5.

3. Yoshii S, Suzuki S, Hosaka S, Osawa H, Takahashi W, Takizawa K, et al. A case of Uhl anomaly treated with one and a half ventricle repair combined with partial right ventriculectomy in infancy. J Thorac Cardiovasc Surg. 2001;122:1026-8.

4. Chachques JC, Argyriadis PG, Fontaine G, Hebert JL, Frank RA, D’Attellis N, et al. Right ventricular cardiomyoplasty: 10-year follow-up. Ann Thorac Surg. 2003; 75:1464-8.

5. Krabatsch T, Potapov E, Stepanenko A, Schweiger M, Kukucka M, Huebler M, et al. Biventricular circulatory support with two miniaturized implantable assist devices. Circulation. 2011;124(11 Suppl):S179-86.

\section{EDITORIAL COMMIENTARY}

\section{Squeezing into a narrow market}

\section{John Matthew Toole, MD}

From the Cardiothoracic Surgery of Charleston, Charleston, SC.

Disclosures: Author has nothing to disclose with regard to commercial support.

Received for publication Feb 10, 2015; accepted for publication Feb 12, 2015; available ahead of print March 24, 2015

Address for reprints: John Matthew Toole, MD, Cardiothoracic Surgery of Charleston, 125 Doughty St, Suite 690, Charleston SC, 29403 (E-mail: toole@ musc.edu).

J Thorac Cardiovasc Surg 2015;149:e116-7

0022-5223/\$36.00

Copyright (c) 2015 by The American Association for Thoracic Surgery

http://dx.doi.org/10.1016/j.jtcvs.2015.02.037
See related article on pages e115-6.

In this issue of the Journal, Potapov and colleagues ${ }^{1}$ report a rare case of Uhl anomaly. This is an extremely rare disease, but more interesting is the full circle of treatment strategy from biologic to mechanical and back to biologic solutions used to treat this problem. 